\title{
Images of the month 3: An unusual case of a red painful eye
}

\author{
Authors: Elliott Lever ${ }^{A}$ and Richard Stratton ${ }^{B}$
}

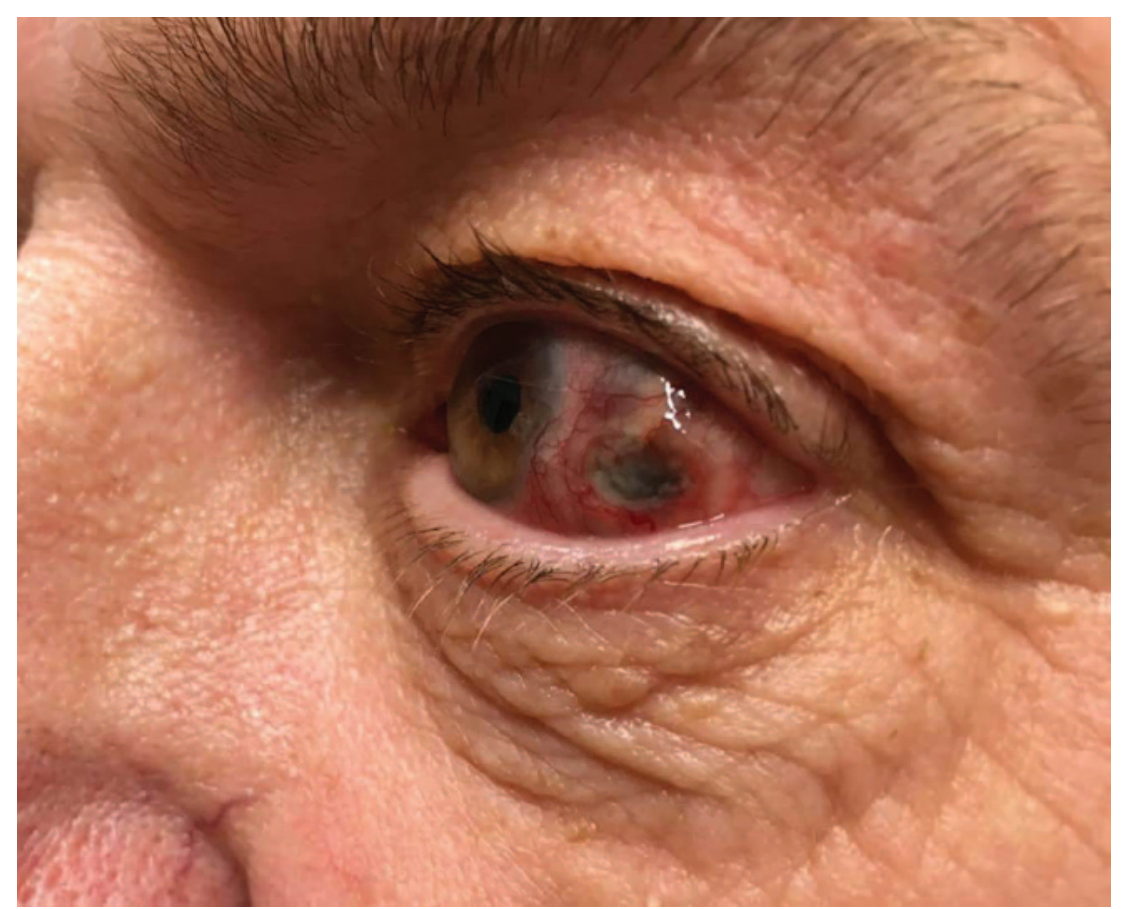

Fig 1. Injection of the sclera, scleromalacia and ulceration, threatening perforation of the eye.
KEYWORDS: Vasculitis, scleritis, MPO, rheumatology, ANCA

\section{Case presentation}

A 68-year-old man presented to the eye clinic with a 3-4-week history of pain in the left eye, which he had noted to be red for the past 12 months. There was no systemic upset. Fig 1 shows injection of the sclera, scleromalacia and ulceration, threatening perforation of the eye. Blood testing revealed haemoglobin of $124 \mathrm{~g} / \mathrm{L}$, white blood cell count of $8.0 \times 10^{9} / \mathrm{L}$, erythrocyte sedimentation rate of 8 hours, $\mathrm{C}$-reactive protein of $7 \mathrm{mg} / \mathrm{L}$, antinuclear antibodies were negative, C-antineutrophil cytoplasm antibodies was positive with positive antibodies

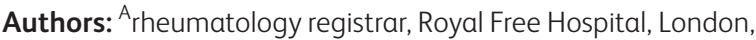
UK; ${ }^{B}$ consultant rheumatologist and associate professor, Royal Free Hospital, London, UK against proteinase 3 ( 83 units/L). Urine dip was negative for blood and protein. He was treated with pulsed methylprednisolone and rituximab, followed by oral prednisolone and low-dose mycophenolate, making an uneventful recovery with preservation of vision. This presentation was of an isolated vasculitic process severely affecting the sclera, with normal inflammatory markers, which is rare. The case highlights how rheumatic conditions can present with ocular disease.

Address for correspondence: Dr Richard Stratton, Centre for Rheumatology and Connective Tissue Diseases, UCL Division of Medicine, Royal Free Hospital, Pond Street, London NW3 2QG, UK.

Email: r.stratton@ucl.ac.uk 